\title{
EFFECT OF DIFFERENT METHODS OF PRESERVATION ON THE QUALITY OF CATTLE AND GOAT MEAT
}

\author{
S. Bin. Faisal, S. Akhter ${ }^{1}$ and M. M. Hossain
}

\begin{abstract}
The study was conducted to evaluate the effect of drying, curing and freezing on the quality of cattle and goat meat collected and designed as. Cattle and goat meat samples were: dried cattle meat with salt $\left(M_{1}\right)$, dried cattle meat without salt $\left(M_{2}\right)$, dried goat meat with salt $\left(M_{3}\right)$, dried goat meat without salt $\left(M_{4}\right)$, cured cattle meat with salt $\left(M_{5}\right)$, cured cattle meat with sugar $\left(M_{6}\right)$, cured goat meat with salt $\left(M_{7}\right)$, cured goat meat with sugar $\left(M_{8}\right)$, frozen cattle meat with salt $\left(M_{9}\right)$, frozen cattle meat without salt $\left(M_{10}\right)$, frozen goat meat with salt $\left(M_{11}\right)$ and frozen goat meat without salt $\left(\mathrm{M}_{12}\right)$ and analyze on every 30 days interval up to the period of 120 days. Chemical constituents of meat samples (dry matter, protein, ash and fat) decreased gradually with the increasing of storage time, but dry matter increased gradually during freezing period. The initial dry matter, ash, protein and fat contents of the samples $\left(M_{1}, M_{2}, M_{3}, M_{4}, M_{5}, M_{6}, M_{7}, M_{8}, M_{9}, M_{10}, M_{11}, M_{12}\right)$ ranged from 81.26 to $98.50 \%, 15.01$ to $22.46 \%, 60.28$ to $77.30 \%$ and 3.04 to $6.70 \%$ and final value were ranged from 80.03 to $88.12 \%, 10.92$ to $18.50 \%, 57.98$ to $68.93 \%$ and 2.50 to $5.90 \%$, respectively. The elapse of storage time quality parameters of meat samples degraded significantly $(P<0.05$ to 0.01$)$. Quality parameters also varied among the samples $(\mathrm{P}<0.05$ to 0.01$)$. Considering fat and protein value of cattle and goat meat, salt drying and sugar curing were better than other preservation methods.
\end{abstract}

Key words: Preservation, Cattle meat, Goat meat, Quality

\section{Introduction}

For inadequacy of food supply people are suffering from malnutrition and diseases which causing adverse effect upon their health and working capacity. Nutrients especially, protein, carbohydrate, fat, minerals and vitamins should be provided through balanced diet. As the human population increases, the protein requirement is also increases. Cattle and goat meat are recognized as highly nutritious food, being an excellent source of high quality animal protein. Meat also contains essential amino acids, vitamins and minerals especially iron.

The annual meat production was 559.00 thousand metric tons (BBS, 2005), where $60.6 \%$ of the total came from cattle, $1.3 \%$ from buffalo, $8.1 \%$ from goat, $0.9 \%$ from sheep and 29.1\% from chicken and duck. In Bangladesh, 23\% of total cattle are being

\footnotetext{
${ }^{1}$ Department of Animal Science, Bangladesh Agricultural University, Mymensingh-2202, Bangladesh
}

(Received: October 07, 2009) 
slaughtered every year, where the extent of slaughtering is about $7 \%$ on a single occasion like Eid-Ul-Azha. The remaining $16 \%$ is slaughtered for meat throughout the year (Alam, 1995). So there is surplus meat production in special occasion which needs to be preserved for future consumption.

There is no appropriate techniques of meat preservation in our country. Some butchers, meat sellers and urban housewives use freezing technique for commercial purpose and home consumption. In most rural areas, there is no definite preservation method. However, the rural housewives sometimes use cooking of meat as very short time preservation technique. Moreover, proper preservation method is a problem in urban areas where appropriate freezing technique of meat is not available. Drying, curing and freezing are the conventional method of meat preservation in our country. The aim of preservation is not only to retard the meat spoilage but also to control undesirable changes of wholesomeness, nutritive value and growth of microorganisms (Fennema, 1975).

Drying is one of the oldest method of inexpensive meat preservation with no energy required, little equipment needed, dry and/or airtight storage required; quality and nutritional value reasonable with good storage. Drying of meat reduces the availability of water that is stored in such a level where microbes can not survive. Curing is one of the methods of meat preservation by adding common salt and sugar. Sugar improves the flavor and salt adversely affect the growth of microorganisms. Freezing is the only known expensive method uses much energy and large investments are needed, nutritional value and storage life of the product are good mainly used in urban areas by which meat can be preserved in a condition similar to their normal state. So, the proper preservation techniques are essential considering the environmental condition and places in our country. Using proper method of preservation, it would be possible to control spoilage of meat, to preserve surplus meat and to increase its shelf life. This study was aimed at the effect of preservation method and storage on the quality of beef and goat meat.

\section{Materials and Methods}

Boneless meats of freshly slaughtered cattle and goat were purchased from "K. R. Market", Mymensingh at 8.00 A.M. The meat samples were immediately transferred to the "Animal Science Laboratory". All visible fat and connective tissues were trimmed off as far possible with the help of knife and the sample was prepared into small pieces. Goat and cattle meats were divided into two parts which were equal in amount. Then the meat was rinsed and washed with clean water properly to make it blood free. The methods of meat preservation and curing agents are shown in Table 1.

After proper mixing the meat samples with curing agents were kept in labeled Petri dish and immediately placed in the oven at $50^{\circ} \mathrm{C}$ for 3 days. The non-salted or fresh cattle and goat meat samples were kept in labeled Petridish and immediately placed in the oven at $50^{\circ} \mathrm{C}$ for 3 days. After 3 days, the dried meat samples were brought out from the 
oven, grinded and packed in polyethylene bags and kept in the plastic jar at room temperature for further analytical evaluations.

Table 1. Methods of meat preservation and curing agent used in the experiment

\begin{tabular}{|l|l|c|l|}
\hline Species & Methods of preservation & Treatments & Proportion of meat sample and curing agent \\
\hline \multirow{5}{*}{ Cattle } & Drying with salt & $\mathrm{M}_{1}$ & $8 \mathrm{~g}$ salt $/ 100 \mathrm{~g}$ meat \\
& Drying without salt & $\mathrm{M}_{2}$ & meat only \\
& Curing with salt & $\mathrm{M}_{5}$ & $8 \mathrm{~g}$ salt $+0.125 \mathrm{mg} \mathrm{kNO} / 100 \mathrm{~g} \mathrm{meat}$ \\
& Curing with sugar & $\mathrm{M}_{6}$ & $8 \mathrm{~g}$ salt $+2 \mathrm{~g} \mathrm{sugar}+0.125 \mathrm{mg} \mathrm{Kno}_{3} / 100 \mathrm{~g}$ meat \\
& Freezing with salt & $\mathrm{M}_{9}$ & $8 \mathrm{~g}$ salt $/ 100 \mathrm{~g}$ meat \\
& Freezing without salt & $\mathrm{M}_{10}$ & meat only \\
\hline \multirow{5}{*}{ Goat } & Drying with salt & $\mathrm{M}_{3}$ & $8 \mathrm{~g}$ salt $/ 100 \mathrm{~g}$ meat \\
& Drying without salt & $\mathrm{M}_{4}$ & meat only \\
& Curing with salt & $\mathrm{M}_{7}$ & $8 \mathrm{~g}$ salt $+0.125 \mathrm{mg} \mathrm{kNO} / 100 \mathrm{~g} \mathrm{meat}$ \\
& Curing with sugar & $\mathrm{M}_{8}$ & $8 \mathrm{~g}$ salt $+2 \mathrm{~g} \mathrm{sugar}+0.125 \mathrm{mg} \mathrm{KNO} / 100 \mathrm{~g}$ meat \\
& Freezing with salt & $\mathrm{M}_{11}$ & $8 \mathrm{~g}$ salt $/ 100 \mathrm{~g}$ meat \\
& Freezing without salt & $\mathrm{M}_{12}$ & meat only \\
\hline
\end{tabular}

The curing agents (salt or sugar) were mixed with the cattle and goat meat (Table 1) carefully. After mixing the samples were kept in labeled jars. The jars were covered by very fine thin cloths and tied by thread. Daily intercultural activities such as moving, enclosing and opening the cover, stirring of meat pieces were done everyday. The curing period was 10 days. After 10 days of curing period, all the samples were brought out from the jars and dried the meat samples placed in the oven at $50^{\circ} \mathrm{C}$ for 3 days. The oven dried meat samples were packed in polyethylene bags and kept in the plastic jars at room temperature.

The salt was mixed with the cattle and goat meat (Table 1) samples. After mixing, the meat samples were wrapped with polyethylene bags and preserved in refrigerator at $10^{\circ} \mathrm{C}$ for 120 days. The non-salted or fresh cattle and goat meat samples were wrapped with polyethylene bags and preserved in refrigerator at $-10^{\circ} \mathrm{C}$ for 120 days. After freezing period, all the samples were brought out from the refrigerator and dried the meat samples placed in the oven at $50^{\circ} \mathrm{C}$ for 3 days. After 3 days of drying, the oven dried meat samples were packed in polyethylene bags and kept in the plastic jars at room temperature for further analytical evaluations.

Proximate analysis such as moisture, ether extract, crude protein and ash were carried out according to the methods of AOAC (2005) at different frozen time. PH value of meat in the form of homogenate was measured using $\mathrm{pH}$ meter. The homogenate was prepared by blending $2 \mathrm{~g}$ of meat with $10 \mathrm{ml}$ distilled water.

Data were analyzed statistically using the analysis of variance (ANOVA) technique in a Completely Randomized Design (CRD) by using MSTAT statistical computer package 
Bang. J. Anim. Sci. 2009, 38(1\&2)

program. Duncan's new Multiple Range Test (DMRT) was done to compare treatment means.

\section{Results and Discussion}

The initial dry matter value was in the range of 81.26 to $98.50 \%$ with lowest in $\mathrm{M}_{10}$ and highest in $M_{8}$. At the end of 120 days storage period, the dry matter value ranged from 80.03 to $88.12 \%$ with minimum in $\mathrm{M}_{8}$ and maximum in $\mathrm{M}_{9}$. However the $\mathrm{DM} \%$ were statistically not significant with each other (Table 2). Dry matter content decreased with the increase of storage period (Table 3) but increased in frozen samples (Table 4). The loss of moisture probably associated with increased dry matter. The same trend was also observed by Konieczny et al. (2007) and they reported that dry matter content increased during frozen storage. The initial value of ash ranged from 15.01 to $22.46 \%$ with lowest in $M_{7}$ and highest in $M_{2}$. At the end of storage ash content was 10.92 to $18.50 \%$ with lowest in $\mathrm{M}_{3}$ and highest in $\mathrm{M}_{9}$ (Table 4). The ash value decreased with the storage time (Table 3).

Table 2. Effect of preservation methods on different parameters

\begin{tabular}{|c|c|c|c|c|c|c|c|c|c|c|c|c|}
\hline \multirow{3}{*}{$\begin{array}{c}\text { Para } \\
\text { meters } \\
(\%)\end{array}$} & \multicolumn{4}{|c|}{ Dried meat } & \multicolumn{4}{|c|}{ Cured meat } & \multicolumn{4}{|c|}{ Frozen meat } \\
\hline & \multicolumn{2}{|c|}{ Cattle } & \multicolumn{2}{|c|}{ Goat } & \multicolumn{2}{|c|}{ Cattle } & \multicolumn{2}{|c|}{ Goat } & \multicolumn{2}{|c|}{ Cattle } & \multicolumn{2}{|c|}{ Goat } \\
\hline & $M_{1}$ & $M_{2}$ & $M_{3}$ & $M_{4}$ & $M_{5}$ & $M_{6}$ & $M_{7}$ & $M_{8}$ & $M_{9}$ & $M_{10}$ & $M_{11}$ & $M_{12}$ \\
\hline DM & 89.58 & 89.66 & 89.94 & 90.96 & 87.4 & 88.45 & 87.91 & 89.08 & 86.6 & 84.06 & 86.3 & 84.47 \\
\hline Ash & $\begin{array}{c}18.73_{a b} \\
c\end{array}$ & $20.32_{a}$ & $13.31_{\mathrm{e}}$ & $15.77_{\mathrm{e}}$ & $14.43_{\mathrm{de}}$ & $13.86_{\mathrm{e}}$ & $13.35_{\mathrm{e}}$ & $13.63_{\mathrm{e}}$ & $19.20_{a b}$ & $\begin{array}{c}16.95_{b c} \\
d\end{array}$ & $\begin{array}{c}18.65_{\mathrm{ab}} \\
\mathrm{c}\end{array}$ & $14.65_{\mathrm{de}}$ \\
\hline $\mathrm{CP}$ & $66.78_{b c}$ & $64.92_{c d}$ & $72.88_{a}$ & $71.62_{a b}$ & $\begin{array}{c}67.71_{a b} \\
c\end{array}$ & $\begin{array}{c}68.40_{a b} \\
c\end{array}$ & $\begin{array}{c}69.87_{a b} \\
c\end{array}$ & $70.81_{\mathrm{ab}}$ & $60.26_{\mathrm{de}}$ & $60.89_{\mathrm{de}}$ & $59.25_{e}$ & $60.07_{\mathrm{de}}$ \\
\hline EE & $3.95_{c d}$ & $4.26_{c}$ & $3.5_{\mathrm{de}}$ & $3.28_{\mathrm{de}}$ & $5.05_{b}$ & $5.96 a$ & $4.52_{b c}$ & $4.22_{c}$ & $3.41_{\mathrm{de}}$ & $2.83_{\mathrm{e}}$ & $4.32_{c}$ & $3.09_{e}$ \\
\hline
\end{tabular}

Mean with different subscripts within same row differ significantly

$M_{1}=$ Dried cattle meat (salt), $M_{2}=$ Dried Cattle meat (without salt), $M_{3}=$ Dried goat meat (salt), $M_{4}=$ Dried goat meat (without salt), $M_{5}=$ Cured cattle meat (salt), $M_{6}=$ Cured cattle meat (sugar), $M_{7}=$ Cured goat meat (salt) $M_{8}=$ Cured goat meat (sugar), $M_{9}=$ Frozen cattle meat (salt), $M_{10}=$ Frozen cattle meat (without salt) $M_{11}=$ Frozen goat meat (salt), $\mathrm{M}_{12}=$ Frozen goat meat (without salt)

Table 3. Effect of storage time (day) on different parameters

\begin{tabular}{|l|c|c|c|c|}
\hline \multirow{2}{*}{$\begin{array}{c}\text { Parameters } \\
\text { (\%) }\end{array}$} & \multicolumn{4}{|c|}{ Storage time (Days) } \\
\cline { 2 - 5 } & $\mathbf{0}$ & $\mathbf{3 0}$ & $\mathbf{6 0}$ & $\mathbf{1 2 0}$ \\
\hline DM & $92.51_{\mathrm{a}}$ & $89.01_{\mathrm{b}}$ & $85.93_{\mathrm{ab}}$ & $84.02_{\mathrm{c}}$ \\
Ash & $18.18_{\mathrm{a}}$ & $16.75_{\mathrm{ab}}$ & $15.25_{\mathrm{bc}}$ & $14.11_{\mathrm{c}}$ \\
CP & $69.90_{\mathrm{a}}$ & $66.96_{\mathrm{ab}}$ & $64.60_{\mathrm{b}}$ & $63.02_{\mathrm{b}}$ \\
EE & $4.52_{\mathrm{a}}$ & $4.23_{\mathrm{ab}}$ & $3.85_{\mathrm{ab}}$ & $3.53_{\mathrm{b}}$ \\
\hline
\end{tabular}

Mean with different subscripts within same row differ significantly

The initial protein content was in the range of 60.28 to $77.30 \%$ with lowest in $\mathrm{M}_{11}$ and highest in $\mathrm{M}_{3}$. At the end of storage time protein values were in the range of 57.98 to $68.93 \%$, minimum in $\mathrm{M}_{12}$ and maximum in $\mathrm{M}_{4}$ (Table 4). The protein content decreased 
with the increase of storage time (Table 3) and the lowest value observed in frozen samples. The loss of protein during storage in those samples may be related with loss of sarcoplasmic protein probably due to the osmosis and poor water holding capacity. Sarcoplasmic protein (water soluble protein) may be lost during frozen storage in the form of drip loss. The result was supported by Baowu et al. (1997). Konieczny et al. (2007) investigated that protein content of beef decreased during frozen storage.

Table 4. Interaction effect of preservation method and storage time

\begin{tabular}{|c|c|c|c|c|c|c|c|c|c|c|c|c|c|}
\hline \multirow{3}{*}{ 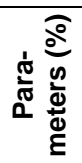 } & \multirow{3}{*}{$\begin{array}{l}\frac{n}{0} \\
\frac{0}{0} \\
0\end{array}$} & \multicolumn{4}{|c|}{ Dried meat } & \multicolumn{4}{|c|}{ Cured meat } & \multicolumn{4}{|c|}{ Frozen meat } \\
\hline & & \multicolumn{2}{|c|}{ Cattle } & \multicolumn{2}{|c|}{ Goat } & \multicolumn{2}{|c|}{ Cattle } & \multicolumn{2}{|c|}{ Goat } & \multicolumn{2}{|c|}{ Cattle } & \multicolumn{2}{|c|}{ Goat } \\
\hline & & $M_{1}$ & $M_{2}$ & $M_{3}$ & $M_{4}$ & $M_{5}$ & $M_{6}$ & $M_{7}$ & $M_{8}$ & $M_{9}$ & $M_{10}$ & $M_{11}$ & $M_{12}$ \\
\hline \multirow{4}{*}{ DM } & 0 & $97.4 \mathrm{a}$ & $96.3_{a}$ & $98.1_{a}$ & $98.0_{a}$ & $95.7_{\mathrm{a}}$ & $96.8_{a}$ & $96.0_{a}$ & & $85.1_{b}$ & & $84.4_{b}$ & $82.4_{b c}$ \\
\hline & 30 & $92.9_{\mathrm{a}}$ & $91.9_{\mathrm{ab}}$ & $91.5_{\mathrm{ab}}$ & $93.0_{\mathrm{a}}$ & $87.9_{\mathrm{bcd}}$ & $90.0_{\mathrm{abc}}$ & $90.0_{\mathrm{abc}}$ & $91.8_{\mathrm{ab}}$ & $86.0_{\text {cde }}$ & $83.7_{\mathrm{de}}$ & $85.7_{\text {cde }}$ & $83.1_{\mathrm{e}}$ \\
\hline & 60 & 84.9 & 86.5 & 87.5 & 87.8 & 84 & 85.9 & 85 & 85.9 & 87.0 & 84.2 & 86.9 & 85.2 \\
\hline & 120 & $83.0_{\mathrm{bcd}}$ & 83. $8_{\mathrm{abcd}}$ & $82.6_{b c d}$ & $85.0_{a b c}$ & 81.cd & $80.9_{\mathrm{cd}}$ & $80.6_{\mathrm{cd}}$ & $80.0_{d}$ & $88.1_{a}$ & $86.9_{\mathrm{ab}}$ & $88.0_{a}$ & $87.0_{\mathrm{ab}}$ \\
\hline \multirow{4}{*}{ Ash } & 0 & $21.8_{a b}$ & $22.4_{a}$ & 16.6 & $18.7_{\mathrm{bcd}}$ & $17.3_{\text {cde }}$ & $16.3_{\mathrm{de}}$ & $15.0_{\mathrm{e}}$ & $16.1_{\mathrm{de}}$ & $20.0_{a b c}$ & $18.1_{\text {cde }}$ & $19.2_{\mathrm{bcd}}$ & $16.1_{\mathrm{de}}$ \\
\hline & 30 & $19.5_{\mathrm{ab}}$ & $21.6_{a}$ & $13.8_{d}$ & $17.2_{b c}$ & $15.1_{c d}$ & $14.3_{d}$ & $14.2_{\mathrm{d}}$ & $14.2_{\mathrm{d}}$ & $19.3_{\mathrm{ab}}$ & $17.3_{\mathrm{bc}}$ & $18.9_{b}$ & $15.0_{\mathrm{cd}}$ \\
\hline & 60 & $17.1_{\mathrm{ab}}$ & $19.2_{\mathrm{a}}$ & $11.8_{d}$ & $14.3_{c d}$ & $13.2_{d}$ & $13.3_{d}$ & $13.1_{d}$ & $13.0_{d}$ & $18.9_{\mathrm{ab}}$ & $16.2_{b c}$ & $18.5_{\mathrm{ab}}$ & $13.9_{c d}$ \\
\hline & 120 & $16.2 \mathrm{a}$ & $17.9_{a}$ & $10.9_{b}$ & $12.8_{b}$ & $11.9_{\mathrm{b}}$ & $11.4_{b}$ & $10.9_{b}$ & $11.1_{b}$ & $18.5_{a}$ & $16.0_{a}$ & $17.9_{a}$ & $13.5_{b}$ \\
\hline \multirow{4}{*}{$\mathrm{CP}$} & 0 & $71.2_{\mathrm{cd}}$ & $68.9_{d}$ & $77.3_{a}$ & $75.5_{a b}$ & $72.6_{b c d}$ & $73.7_{\mathrm{abc}}$ & $75.9_{\mathrm{ab}}$ & $77.1_{\mathrm{a}}$ & $61.7_{\mathrm{e}}$ & $62.2_{e}$ & $60.2_{e}$ & $62.1_{\mathrm{e}}$ \\
\hline & 30 & $69.2_{b c}$ & $65.6_{d}$ & $73.7_{a}$ & $72.1_{\mathrm{ab}}$ & $67.5_{\mathrm{cd}}$ & $69.2_{b c}$ & $70.8_{a b c}$ & $72.6_{a}$ & $60.6_{e}$ & $61.8_{\mathrm{e}}$ & $59.8_{e}$ & $60.2_{\mathrm{e}}$ \\
\hline & 60 & $63.9_{\mathrm{de}}$ & $63.2_{\text {ef }}$ & $71.9_{\mathrm{a}}$ & $69.9_{\mathrm{ab}}$ & $65.6_{\text {cde }}$ & $66.4_{\mathrm{cd}}$ & $67.2_{b c}$ & $68.3_{b c}$ & $59.5 \mathrm{~g}$ & $60.4_{\mathrm{fg}}$ & $58.7_{\mathrm{g}}$ & $59.8_{g}$ \\
\hline & 120 & $62.7_{\mathrm{cd}}$ & $61.8_{\mathrm{de}}$ & $68.5_{\mathrm{ab}}$ & $68.9_{a}$ & $64.9_{\mathrm{cd}}$ & $64.2_{\mathrm{cd}}$ & $65.5_{\mathrm{bc}}$ & $65.1_{c d}$ & $59.1_{\text {ef }}$ & $58.9_{\text {ef }}$ & $58.1_{f}$ & $57.9_{f}$ \\
\hline \multirow{4}{*}{ EE } & 0 & $4.2_{\mathrm{cd}}$ & $4.8 b_{c d}$ & $4.0_{c d}$ & $3.6_{d}$ & $5.5_{b}$ & $6.7_{\mathrm{a}}$ & $5.0_{\mathrm{ab}}$ & $4.9_{\mathrm{bc}}$ & $4.0_{c d}$ & $3.0_{d}$ & $4.7_{\mathrm{bcd}}$ & $3.6_{d}$ \\
\hline & 30 & $4.0_{c d}$ & $4.5_{b c}$ & $3.7_{\mathrm{de}}$ & $3.4 d_{\text {ef }}$ & $5.1_{b}$ & $6.2_{\mathrm{a}}$ & $4.8_{b}$ & $4.6_{b}$ & $3.5_{\text {def }}$ & $2.9_{f}$ & $4.5_{b c}$ & $3.2_{\text {def }}$ \\
\hline & 60 & $3.9_{d}$ & $3.9_{d}$ & $3.2_{\mathrm{e}}$ & $3.1 d_{\mathrm{ef}}$ & $4.9_{\mathrm{b}}$ & $5.8 a$ & $4.3_{c}$ & $3.9_{d}$ & $3.0_{\text {def }}$ & $2.8_{\mathrm{g}}$ & $4.1_{c d}$ & $2.9_{\mathrm{fg}}$ \\
\hline & 120 & $3.7_{\mathrm{cd}}$ & $3.7_{c d}$ & $3.0 \mathrm{~d}_{\mathrm{ef}}$ & $2.9_{\text {ef }}$ & $4.6_{a b}$ & $5.0_{a}$ & $3.9_{b c}$ & $3.3 c_{d e}$ & $3.0_{\text {def }}$ & $2.5_{f}$ & $3.9_{\mathrm{bc}}$ & $2.5_{f}$ \\
\hline
\end{tabular}

Mean with different subscripts within same row differ significantly

The initial fat content was in the range of 3.04 to $6.70 \%$ with lowest value in $M_{10}$ and the highest value in $\mathrm{M}_{6}$ ). At the end of storage, the values were in the range of 2.50 to $5.90 \%$, with minimum in $\mathrm{M}_{10}$ and $\mathrm{M}_{12}$ and maximum in $\mathrm{M}_{6}$ (Table 4). Fat value gradually decreased with increasing storage period (Table 3). The decrease of fat content in $M_{10}$ and $\mathrm{M}_{12}$ are probably associated with the presence of potassium Nitrate. Percentage of fat of all samples were highly significant $(P<0.01)$. The interaction effect of storage time and preservation methods are summarized in Table 4. The results indicated that with the elapse of storage time quality parameters of meat sample degraded significantly $(P<0.01)$.

\section{Conclusion}


Bang. J. Anim. Sci. 2009, 38(1\&2)

Quality parameters of meat samples degraded significantly $(P<0.05$ to 0.01$)$ with the elapse of storage time. Quality parameters also varied among the samples $(P<0.05$ to 0.01). Salt drying and sugar curing methods were suitable for preservation considering fat and protein value in both species. Valcant difference compared with those of non salted samples.

\section{Literature Cited}

Alam, J. 1993. Livestock resource of Bangladesh. Present Status and Future Potential, University Press Limited. Dhaka Bangladesh.

AOAC. 2005. Official methods of Analysis. Association of Official Analytical Chemist. Washington, DC.

BBS, 2005. Statistical year book at Bangladesh. Bangladesh Bureau of Statistics. Ministry of Planning, Planning Division, Government of the Peoples Republic of Bangladesh.

Fennema, O. R. 1975. Introduction to food preservation. In: principles of food Science. (Ed. O. R. Fennema) .Marcel Dekker, Inc. New York. pp. 1-7.

Konieczny, P., Stangierski, J. and Kijowski, J. 2007. Physical and chemical characteristics and acceptability of home style beef jerky. Meat Science, 76 (2): 253-257.

Wang ,B; Yuoling; Xiong, L. and Srinivasan, S. 1997. Beef heart surimi was prepared. Journal of Food Science, 62(5): 939-945. 